\title{
THE IMPACT OF CUSTOMER CONTACT AS PART OF \\ THE AGRICULTURAL PRODUCTS DISTRIBUTION CHANNEL \\ ON THE INCREASE OF THE COMPETITIVENESS \\ OF AGRICULTURAL HOLDINGS
}

\author{
Jelena Milanovićl, Zorana Nikitović ${ }^{2}$, Dušan Garabinović3 \\ *Corresponding author E-mail: dusan.garabinovic.032@gmail.com
}

\begin{abstract}
A R T I C LE IN F O
Original Article

Received: 30 January 2020

Accepted: 30 April 2020

doi:10.5937/ekoPolj2002359M

UDC 658.89:[339.13:338.432

Keywords:

distribution, distribution channels, agricultural products, competitiveness, contact with buyers, agricultural holdings

JEL: $Q 13$

A B S T R A C T

The main objective of this paper stems from the need to provide new insights into the competitiveness of the agricultural products distribution system in the Republic of Serbia, through determining the impact of customer contact as part of the agricultural distribution channel on the competitiveness of agricultural holdings. The survey was conducted on a sample of 126 farms from the territory of the Republic of Serbia through a closed-type survey (12 claims related to customer contact and 15 claims related to the competitiveness of the agricultural products distribution system; five-stage Likert scale), which was distributed electronically. The contribution of the paper is reflected in the results which showed that the level of customer contact (as part of the distribution channel) influences the level of competitiveness of the agricultural products distribution system (in the Republic of Serbia). The results also form the basis for further research in this field.
\end{abstract}

(C) 2020 EA. All rights reserved.

\section{Introduction}

Competitiveness can be defined in different ways. It can be "the fact of being able to compete successfully with other companies, countries, organizations, etc.," or "the fact of a person wanting very much to win or be more successful than other people" (Cambridge Dictionary), or "the ability of a country (region, location) to deliver the

1 Jelena Milanović, PhD Student, Agricultural University, Bul. Mendeleev 12, Plovdiv, Bulgaria, Phone: +381641172429, E-mail: ekskurzije@vivatravel.rs, ORCID ID https:// orcid.org/0000-0002-0367-863X

2 Zorana Nikitović, Associate Professor, Faculty of Business Economics and Entrepreneurship, Vojvode Vlahovića 65b, Belgrade, Serbia, Phone: +381642391289, E-mail: zorana. nikitovic@vspep.edu.rs, ORCID ID https://orcid.org/0000-0003-1443-7345

3 Dušan Garabinović, Higher business school of vocational studies "Prof. dr Radomir Bojković”, Topličina 12, 37000 Kruševac, Serbia, Phone: +381643929596, E-mail: dusan. garabinovic.032@gmail.com, ORCID ID https://orcid.org/0000-0002-6247-3060

http://ea.bg.ac.rs 
beyond GDP goals for its citizens" (Aiginger et al., 2013, p. 1). Competitiveness is, therefore, an indicator of the position that an analyzed entity occupies on a particular market, its ability to cope with direct or indirect competitors in the right way, but also a key source of creating opportunities for business improvement and long-term success.

Competitiveness is pursued in all spheres of economic life as well as in the field of agriculture, all in accordance with the main trends that dominate in this field, such as (1) technological advancement, (2) production, price and market directions, (3) changes in consumer habits and (4) climate change (SEEDEV, 2017, pp. 9-130). "The distribution of competitiveness in the world is increasingly pronounced. However, there is no country in the world that does not cultivate or export agricultural products" (SEEDEV, 2017, p. 7).

Regarding the state of the agricultural sector of the Republic of Serbia, Serbia's competitive advantages in the field of agriculture can be divided into the following: Farmers, Regional specialization, Free land, Trade contracts, European Union, IPARD Fund, Quality, the Danube, the Domestic market (SEEDEV, 2017, pp 21-23). According to Aničić et al. (2018) "serious efforts are necessary for structural reforms in the sector of agriculture and rural areas, with the aim of strengthening” (p. 198), thus highlighting the significant role of economic policy impact.

The distribution of agricultural products should certainly be mentioned as one of the important elements of competitiveness in agriculture. The term distribution is a multifaceted term denoting the division of a whole into parts, division, supply, delivery, delivery (of goods, electricity and the like), distribution of objects by class, category, supply and distribution of something to someone or somewhere. Distribution generally means the dispersion, that is, the flow of tangible and intangible goods between producers and consumers, i.e. producers and users, regardless of the spatial and temporal dimensions (mega, global, macro and microdimensions), the type and complexity of distribution channels, physical distribution and logistical distribution (Segetlija, 2006, p. 96).

Physical distribution and distribution channels, as the two basic elements of the distribution system, play a significant role in activities related to agricultural products. Obviously, the distribution characteristics of agricultural products are determined by the characteristics of the products themselves.

Accordingly, some of the characteristics of agricultural product distribution are as follows, according to Lu et al. (2004): “(1) The dispersion characteristic of produce distribution link, (2) The regional characteristic of circulation distribution link, (3) The specified distribution facilities, (4) Integrative characteristic of delivering and trade (the trading process accomplished by distribution)" (p. 171).

According to Kotler and Keller (2006), marketing channels are one of the key concepts in marketing (p. 26). They state that "a marketer uses distribution channels to display, sell or deliver a physical product to a customer or user" (Kotler, Keller, 2006, p. 26). "They 
include distributors, wholesalers, retailers and agents" (Kotler, Keller, 2006, p. 26). According to Lamb et al. (2011), "formally, a marketing channel (also called a channel of distribution) is a business structure of interdependent organizations that are involved in the process of making a product or service available for use or consumption by end customers or business users. Marketing channels facilitate the physical movement of goods from location to location, thus representing "place" or "distribution" in the marketing mix (product, price, promotion, and place) and encompassing the processes involved in getting the right product to the right place at the right time" (p. 417).

Direct access to the target market is usually associated with the traditional view of customer contact as part of the distribution channel in the field of agricultural products. In regards to potential sales of farm products (at home), it is important to answer the following questions: Where is the producer (farm) located?, How far away is the farm from the customer market?, How long does it take for buyers to arrive from their place of residence to the farm?, How can one get to the farm?, What are the travel costs?, Is the farm sufficiently prepared and 'representative' enough to receive customers?, etc.

Farmers can possess facilities in the immediate vicinity of the farm or in slightly more remote locations to allow buyers to more easily reach the desired product, significantly eliminating the disadvantages of selling on the farm itself.

Tourism plays an increasingly important role in the distribution of agricultural products. For example, wine tourism is increasingly relevant not only in practice but also in scientific research. This is confirmed by the research by Anđelić et al. (2019), where is concluded that in journals which names refer directly to the tourism/tourist (from Journal Citation Report - JCR with Impact Factor - IF) the greatest number of papers about wine and wine tourism was published in the $21^{\text {st }}$ century $(94.51 \%)$, especially in its second decade (57.14\%) (p. 1081).

Agritourism, which is largely farm based, is a form of contact with customers and more widely the potential form of agricultural products distribution. Agritourism has received increasing academic attention in recent decades. The above is confirmed by Dimitrovski et al. (2019) who conducted a bibliometric analysis of Crossref agritourism literature indexed in Web of Science (keyword analysis results: 21 papers in 9 journals), finding that agritourism is also related to other forms of tourism (rural tourism, farm tourism) but also with entrepreneurship, authenticity and rural areas (pp. 28-31).

The market is one of the traditional places where direct contact is made between sellers and buyers of agricultural products. Although this form of sales/communication has existed since ancient times, markets are still very popular in agricultural trade today. This is supported by the fact that almost every town in Serbia has its own market area, and market days, in most places, are still the main days of the week for trading agricultural products. According to Duvnjak (2013), the strengths of the market industry in Serbia are the following: "a variety of offer, good market locations, quality, tradition, direct contact of buyer and manufacturer (seller), model of sales from field to table, positive customer opinion, better (organic, domestic) food, flexibility and the ability to 
adapt to change, to apply the experiences of developing and European Union countries, a joining of administrations in joint projects, standardization of services" (p. 27). According to Duvnjak (2013), the weaknesses relate to the following: "a lack of clear vision of development, a deterioration of the market position, infrastructural equipment, market equipment, influence of local governments/policies, frequent changes of top management, undefined legal regulations, inconsistency in their implementation, an absence of promotional activities" (p. 28).

The results of the study by Zaric et al. (2016) in the Republic of Serbia (Zeleni Venac Market and New Belgrade Market in Block 45) relating to the ways of advertising goods in direct marketing and the marketing channels used (p. 64) can be seen in the following figure (Figure 1.).

Figure 1. Advertising of goods in direct marketing (left) and marketing channels (right)

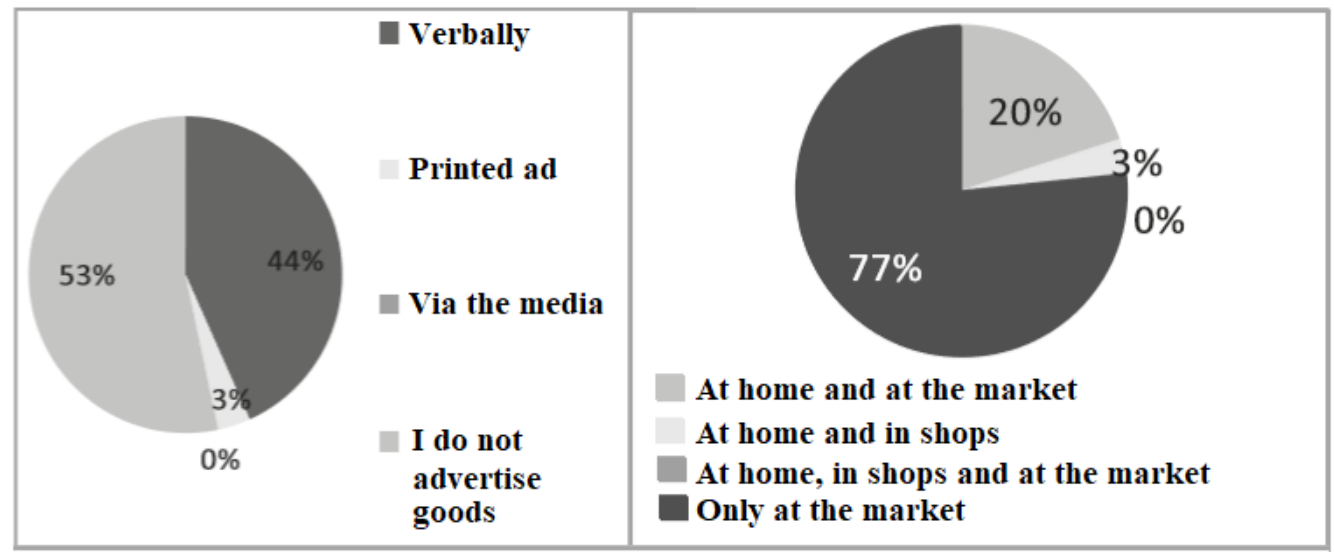

Source: Adapted according to Zarić et al. (2016, pp. 69-70)

Of course, in addition to direct customer contact, there are indirect ways of communicating with customers, whereupon there are one or more intermediaries between the manufacturer and the buyer. It is these intermediaries (primarily wholesale and retail) that can have a significant impact on the relationship of customers with the product.

The importance of food placement media can be seen in the fact that, according to a survey conducted in Nišava district (Serbia), ,60\% of the respondents who participated in the survey had trust in information about organic products which is published in the media“" (Ilić, 2016, p. 175). According to Gajdić et al. (2018) the main distribution channels for organic food products (in Croatia) are direct sales to consumers (60.6\%), sales via mediators (wholesale, retail) $(13.6 \%)$, equally market directly or via mediators $(19.7 \%)$, and Internet sales $(6.0 \%)$ (p. 1473).

A study conducted by Zakić et al. (2017) showed that innovation should not be tied solely to the technology sector, since companies from the agricultural and food sectors are also prone to innovation. Zakić et al. (2017) "conclude that the food sector (31.38\%) tend to be 
more open to innovation in relation to agricultural one $(23.86 \%)$. The reasons for this may lie in the traditionally more conservative nature of the participants in agriculture compared to those in the industry, but also somewhat different processes that occurred in these two sectors during the process of transition to a market economy" (p. 69). The role of the Internet is also important in making contact with customers. Becić et al. (2018) highlight the role of marketing and social networks in enhancing business effectiveness, stating that "absolutely necessary for the managers and marketers to fully comprehend and understand the importance and possibilities and daner of using $21^{\text {st }}$ century technologies, and to turn the flow in their advance" (p. 83). Accordingly, Ćirić et al. (2018) conducted a survey (2016; Autonomous Province of Vojvodina; 125 respondents; questionnaire) (p. 248), which found that most farmers use the Internet every day (53.60\%; 23.20\% are not Internet users), while the highest percentage of respondents never use the analyzed social media (Twitter $-90.40 \%$; Instagram $-76.00 \%$; Facebook $-49.60 \%$; YouTube - 32.00\%) (p. 250). This clearly shows that a greater use of the potential of new technologies in the field of agriculture is necessary.

The subject of this paper is to analyze the connection between customer contact (as part of the agricultural distribution channel) and the competitiveness of the agricultural distribution system. The main objective of this paper stems from the need to provide new insights into the competitiveness of the agricultural products distribution system in the Republic of Serbia, through determining the impact of customer contact as part of the agricultural distribution channel on the competitiveness of agricultural holdings. The above mentioned object and purpose of the paper leads to the following hypothesis: The level of customer contact influences the level of competitiveness of the agricultural products distribution system.

In accordance with the subject, purpose and hypothesis of the paper, a research was conducted related to customer contact as part of the distribution channel of agricultural products in the Republic of Serbia (12 claims) and the competitiveness of the agricultural products distribution system (15 claims).

The contribution of this paper is reflected in the importance of increasing the competitiveness of the agricultural distribution system, especially from the point of view of contact with customers as part of the distribution channel of agricultural products in the territory of the Republic of Serbia (in which agriculture has a significant place in the total economic activities). The research results also form the basis for further research in this field, both in agriculture and in other fields of economy.

\section{Materials and methods}

A survey was conducted on 126 respondents (agricultural holdings) from the territory of the Republic of Serbia. In the realization of the research, the survey method was used based on the developed questionnaire, which was distributed electronically. The survey questionnaire consisted of 12 customer contact claims (hereinafter: CC) as part of the agricultural distribution channel. The paper also makes 15 claims regarding the competitiveness of the agricultural products distribution system (hereinafter: CAPDS). 
The questionnaire included claims with which the respondents gave their opinion based on a five-level Likert scale: 1 - strongly disagree, 2 - disagree, 3 - neither agree nor disagree, 4 - agree and 5 - strongly agree.

\section{Results and Discussions}

The results of the research will be presented below in three parts: (1) Descriptive statistics of claims related to Customer contact (CC1-CC12), (2) Descriptive statistics of claims related to the competitiveness of the agricultural products distribution system (CAPDS1-CAPDS15), (3) Correlation and regression analysis.

\section{1) Descriptive statistics of customer contact claims}

Claim 1 (CC1 - Direct customer contact is helpful) has a mean rating of 3.9761905 and a standard deviation of 1.1625096 . The frequencies of attitude representation are shown in the chart. The highest rating is 5 (strongly agree) - 56 out of 126 respondents $(44.44 \%)$.

Claim 2 (CC2 - Markets are a useful place to contact customers) has a mean score of 3.8253968 and a standard deviation of 1.200529. The frequencies of attitude representation are shown in the chart. Ratings 4 (strongly agree) and 5 (strongly agree) are most represented - 44 out of 126 respondents $(34.92 \%$ each).

Claim 3 (CC3 - Retail is a significant source of information on customer preferences) has a mean rating of 3.6825397 and a standard deviation of 1.0855472 . The frequencies of attitude representation are shown in the chart. The most represented rating is 4 (I agree) -44 out of 126 respondents $(34.92 \%)$.

Claim 4 (CC4 - Wholesale stores are increasingly important places for customer contact) has a mean score of 4.015873 and a standard deviation of 1.1592006 . The frequencies of attitude representation are shown in the chart. The highest rating is 5 (strongly agree) - 56 out of 126 respondents $(44.44 \%)$.

Claim 5 (CC5 - Markets are important for meeting customer wants and needs) has a mean rating of 4.0952381 and a standard deviation of 1.1058287 . The frequencies of attitude representation are shown in the chart. The most represented grade is 5 (strongly agree) -59 out of 126 respondents $(46.82 \%)$.

Claim 6 (CC6 - Higher agricultural product quality leads to binding customers to the product) has a mean score of 3.88888889 and a standard deviation of 1.1539305 . The frequencies of attitude representation are shown in the chart. The most represented rating is 5 (strongly agree) - 50 out of 126 respondents $(39.68 \%)$.

Claim 7 (CC7 - Farm name or brand affect customer loyalty) has a mean score of 3.9603175 and a standard deviation of 1.0150925. The frequencies of attitude representation are shown in the chart. The most represented rating is 4 (agree) - 63 out of 126 respondents $(50.00 \%)$. 
Claim 8 (CC8 - A larger range of agricultural products leads to customer attachment) has a mean score of 3.7619048 and a standard deviation of 1.1553602 . The frequencies of attitude representation are shown in the chart. The most represented rating is 4 (agree) - 54 out of 126 respondents $(42.85 \%)$.

Claim 9 (CC9 - A faithful buyer is significant for the long-term survival of the farm) has a mean score of 3.9603175 and a standard deviation of 1.551678 . The frequencies of attitude representation are shown in the chart. The most represented rating is 4 (I agree) -50 out of 126 respondents $(39.68 \%)$.

Claim 10 (CC10 - Frequent buyers lead to profit increase) has a mean score of 4.1031746 and a standard deviation of 1.1442333. The frequencies of attitude representation are shown in the chart. The highest rating is 5 (strongly agree) -63 out of 126 respondents $(50.00 \%)$.

Claim 11 (CC11 - Good customer relations are important for long-term planning for a distribution strategy) has a mean rating of 4.2222222 and a standard deviation of 1.1585431. The frequencies of attitude representation are shown in the chart. The most represented rating is 5 (strongly agree) - 75 out of 126 respondents $(59.52 \%)$.

Claim 12 (CC12 - Loyal customers significantly impact the planning of a distribution strategy) has a mean rating of 4.0634921 and a standard deviation of 1.1781072 . The frequencies of attitude representation are shown in the chart. The highest rating is 5 (strongly agree) - 63 out of 126 respondents $(50.00 \%)$.

The table (Table 1.) shows the basic descriptive statistics for the above claims (CC1-CC12).

Table 1. Descriptive statistics for CAPDS1-CAPDS15 claims

\begin{tabular}{|l|r|r|r|r|r|r|}
\hline & \multicolumn{1}{|c|}{ Mean } & \multicolumn{1}{|c|}{ Std Dev } & $\begin{array}{c}\text { Std Err } \\
\text { Mean }\end{array}$ & $\begin{array}{c}\text { Upper 95\% } \\
\text { Mean }\end{array}$ & $\begin{array}{c}\text { Lower 95\% } \\
\text { Mean }\end{array}$ & N \\
\hline CC1 & 3.9761905 & 1.1625096 & 0.1035646 & 4.1811576 & 3.7712233 & 126 \\
\hline CC2 & 3.8253968 & 1.200529 & 0.1069516 & 4.0370674 & 3.6137263 & 126 \\
\hline CC3 & 3.6825397 & 1.0855472 & 0.0967082 & 3.8739373 & 3.4911421 & 126 \\
\hline CC4 & 4.015873 & 1.1592006 & 0.1032698 & 4.2202568 & 3.8114893 & 126 \\
\hline CC5 & 4.0952381 & 1.1058287 & 0.0985151 & 4.2902116 & 3.9002646 & 126 \\
\hline CC6 & 3.8888889 & 1.1539305 & 0.1028003 & 4.0923434 & 3.6854343 & 126 \\
\hline CC7 & 3.9603175 & 1.0150925 & 0.0904316 & 4.1392929 & 3.7813421 & 126 \\
\hline CC8 & 3.7619048 & 1.1553602 & 0.1029277 & 3.9656114 & 3.5581981 & 126 \\
\hline CC9 & 3.9603175 & 1.1551678 & 0.1029105 & 4.1639902 & 3.7566448 & 126 \\
\hline CC10 & 4.1031746 & 1.1442333 & 0.1019364 & 4.3049194 & 3.9014298 & 126 \\
\hline CC11 & 4.2222222 & 1.1585431 & 0.1032112 & 4.42649 & 4.0179544 & 126 \\
\hline CC12 & 4.0634921 & 1.1781072 & 0.1049541 & 4.2712093 & 3.8557748 & 126 \\
\hline
\end{tabular}

Source: Authors' research

The figure (Figure 2.) shows the frequency of the respondent responses to the analyzed claims (CC1-CC12). 
Figure 2. Frequency of respondent responses to $\mathrm{CC} 1-\mathrm{CC} 12$ claims

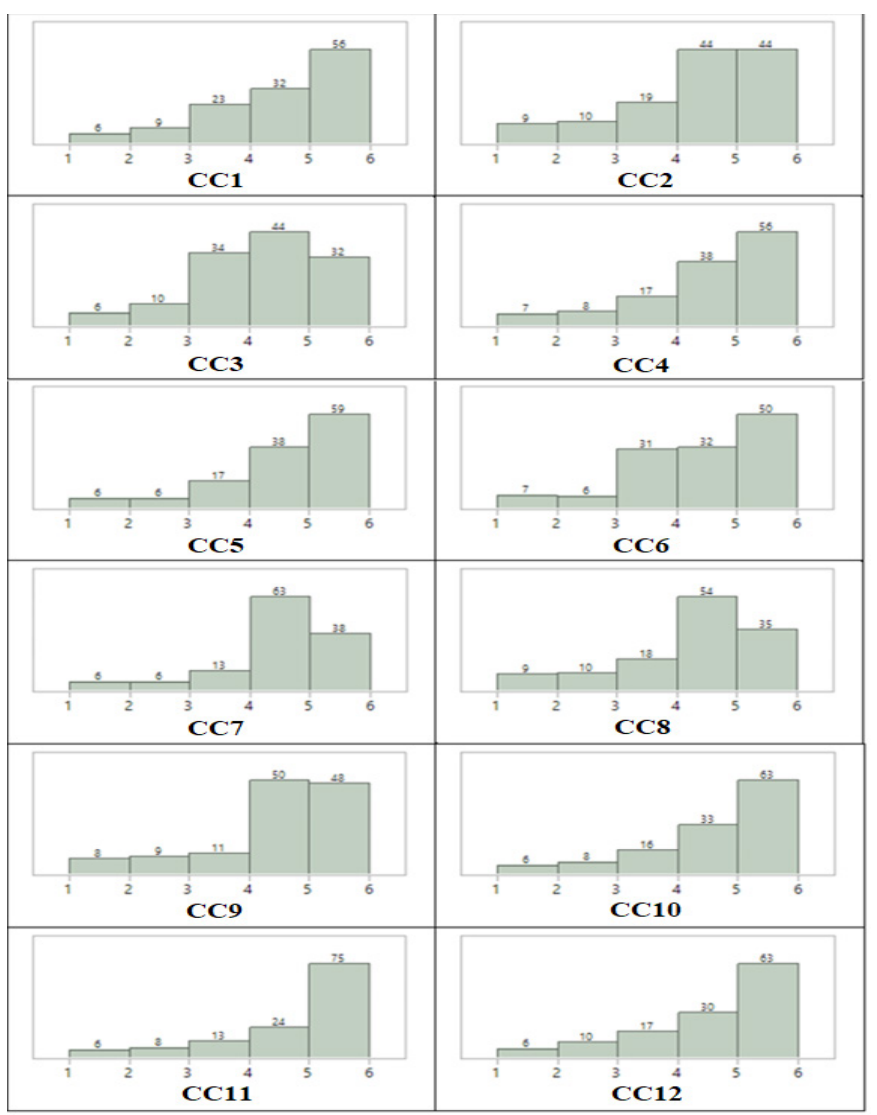

Source: Authors' research

Based on the tables and in accordance with the average rating of the claims analyzed, the order of significance of the asserted claims is as follows: CC11 (4.222222), CC10 (4.103175), CC5 (4.095238), CC12 (4.063492), CC4 (4.015873), CC1 (3.976191s), CC7 (3.960318), CC9 (3.960318), CC6 (3.888889), CC2 (3.825397), CC8 (3.761905) and CC3 (3.68254).

\section{2) Descriptive statistics of claims regarding the Competitiveness of the agricultural products distribution system}

Claim 1 (CAPDS1 - Investments affect the competitiveness of the agricultural products distribution system) has a mean score of 3.9444444 and a standard deviation of 1.1545081 . The frequencies of attitude representation are shown in the chart. The most represented rating is 4 (agree) - 50 out of 126 respondents (39.68\%).

Claim 2 (CAPDS2 - The application of modern technologies increases the competitiveness of the agricultural products distribution system) has a mean score of 3.8253968 and a standard 
deviation of 1.200529. The frequencies of attitude representation are shown in the chart. The most represented ratings are 4 and 5 (agree and strongly agree) - 44 out of 126 respondents (34.92\% each).

Claim 3 (CAPDS3 - Warehouse modernization leads to an increased competitiveness of the agricultural products distribution system) has a mean score of 4.0952381 and a standard deviation of 1.0985705. The frequencies of attitude representation are shown in the chart. The highest rating is 5 (strongly agree) - 57 out of 126 respondents $(45.23 \%)$.

Claim 4 (CAPDS4 - Transportation management significantly affects the competitiveness of the agricultural products distribution system) has a mean score of 4.1031746 and a standard deviation of 1.0941983. The frequencies of attitude representation are shown in the chart. The highest rating is 5 (strongly agree) - 58 out of 126 respondents $(46.03 \%)$.

Claim 5 (CAPDS5 - Adequate commodity handling contributes to greater competitiveness of the agricultural products distribution system) has a mean score of 4.031746 and a standard deviation of 1.1309218. The frequencies of attitude representation are shown in the chart. The most represented rating is 5 (strongly agree) - 56 out of 126 respondents $(44.44 \%)$.

Claim 6 (CAPDS6 - Order processing has a significant impact on the competitiveness of the agricultural products distribution system) has a mean score of 3.8650794 and a standard deviation of 1.0980213. The frequencies of attitude representation are shown in the chart. The most represented rating is 5 (strongly agree) - 44 out of 126 respondents $(34.92 \%)$.

Claim 7 (CAPDS7 - Inventory management affects the competitiveness of the agricultural products distribution system) has a mean score of 4.015873 and a standard deviation of 1.1098405. The frequencies of attitude representation are shown in the chart. The most represented rating is 5 (strongly agree) - 51 out of 126 respondents $(40.47 \%)$.

Claim 8 (CAPDS8 - The point of sale has an impact on increasing the competitiveness of the agricultural products distribution system) has a mean score of 4.0793651 and a standard deviation of 1.1496307 . The frequencies of attitude representation are shown in the chart. The most represented rating is 5 (strongly agree) - 61 out of 126 respondents $(48.41 \%)$.

Claim 9 (CAPDS9 - Direct customer contact has a significant impact on competitiveness) has a mean rating of 3.9884127 and a standard deviation of 1.1522786 . The frequencies of attitude representation are shown in the chart. The highest rating is 5 (strongly agree) - 50 out of 126 respondents $(39.68 \%)$.

Claim 10 (CAPDS10 - Linking related farms leads to an increase of the competitiveness of the agricultural products distribution systems) has a mean score of 3.7142857 and a standard deviation of 1.1232606. The frequencies of attitude representation are shown in chart 97 . The highest rating is 4 (agree) - 57 out of 126 respondents $(45.23 \%)$.

Claim 11 (CAPDS11 - Familiarity of the farm with the functioning of the market leads to strengthentening of the competitive position) has a mean of 4.2301587 and a standard deviation of 1.0819442. The frequencies of attitude representation are shown in the chart. The highest rating is 5 (strongly agree) - 67 out of 126 respondents $(53.17 \%)$. 
Claim 12 (CAPDS12 - Introducing innovation in all elements of physical distribution leads to increasing the competitiveness of the agricultural products distribution systems) has a mean score of 4.1666667 and a standard deviation of 1.1366618 . The frequencies of attitude representation are shown in the chart. The highest rating is 5 (strongly agree) - 68 out of 126 respondents $(53.96 \%)$.

Claim 13 (CAPDS13 - Agood distributor relationship affects competitiveness) has a mean score of 4.1349206 and a standard deviation of 1.1052831 . The frequencies of attitude representation are shown in the chart. The most represented grade is 5 (strongly agree) - 62 out of 126 respondents (49.20\%).

Claim 14 (CAPDS14 - A good selection of distribution channels significantly increases the competitiveness of the agricultural products distribution system) has a mean score of 4.0634921 and a standard deviation of 1.1436505. The frequencies of attitude representation are shown in the chart. The most represented rating is 5 (strongly agree) -60 out of 126 respondents (47.61\%).

Claim 15 (CAPDS15 - Lower transportation costs, fast and accurate delivery of goods affect the competitiveness of the agricultural products distribution system) has a mean score of 3.9126984 and a standard deviation of 1.1244187. The frequencies of attitude representation are shown in the chart. The highest rating is 5 (strongly agree) - 50 out of 126 respondents $(39.68 \%)$.

The table (Table 2.) shows the basic descriptive statistics for the above statements (CAPDS1CAPDS15).

Table 2. Descriptive statistics for CAPDS1-CAPDS15 claims

\begin{tabular}{|l|r|r|r|r|r|r|}
\hline & \multicolumn{1}{|c|}{ Mean } & \multicolumn{1}{|c|}{ Std Dev } & $\begin{array}{c}\text { Std Err } \\
\text { Mean }\end{array}$ & $\begin{array}{c}\text { Upper 95\% } \\
\text { Mean }\end{array}$ & $\begin{array}{c}\text { Lower 95\% } \\
\text { Mean }\end{array}$ & N \\
\hline CAPDS1 & 3.9444444 & 1.1545081 & 0.1028518 & 4.1480008 & 3.7408881 & 126 \\
\hline CAPDS2 & 3.8253968 & 1.200529 & 0.1069516 & 4.0370674 & 3.6137263 & 126 \\
\hline CAPDS3 & 4.0952381 & 1.0985705 & 0.0978684 & 4.2889319 & 3.9015443 & 126 \\
\hline CAPDS4 & 4.1031746 & 1.0941983 & 0.0974789 & 4.2960975 & 3.9102517 & 126 \\
\hline CAPDS5 & 4.031746 & 1.1309218 & 0.1007505 & 4.2311438 & 3.8323482 & 126 \\
\hline CAPDS6 & 3.8650794 & 1.0980213 & 0.0978195 & 4.0586763 & 3.6714824 & 126 \\
\hline CAPDS7 & 4.015873 & 1.1098405 & 0.0988725 & 4.2115539 & 3.8201922 & 126 \\
\hline CAPDS8 & 4.0793651 & 1.1496307 & 0.1024172 & 4.2820615 & 3.8766686 & 126 \\
\hline CAPDS9 & 3.984127 & 1.1522786 & 0.1026531 & 4.1872903 & 3.7809637 & 126 \\
\hline CAPDS10 & 3.7142857 & 1.1232606 & 0.100068 & 3.9123327 & 3.5162387 & 126 \\
\hline CAPDS11 & 4.2301587 & 1.0819442 & 0.0963872 & 4.4209211 & 4.0393964 & 126 \\
\hline CAPDS12 & 4.1666667 & 1.1366618 & 0.1012619 & 4.3670765 & 3.9662568 & 126 \\
\hline CAPDS13 & 4.1349206 & 1.1052831 & 0.0984664 & 4.329798 & 3.9400433 & 126 \\
\hline CAPDS14 & 4.0634921 & 1.1436505 & 0.1018845 & 4.2651341 & 3.86185 & 126 \\
\hline CAPDS15 & 3.9126984 & 1.1244187 & 0.1001712 & 4.1109496 & 3.7144472 & 126 \\
\hline
\end{tabular}

Source: Authors' research 
The figure (Figure 3.) shows the frequency of respondent responses to the analyzed claims (CAPDS1-CAPDS15).

Figure 3. Frequency of respondent responses to CAPDS1-CAPDS15 claims

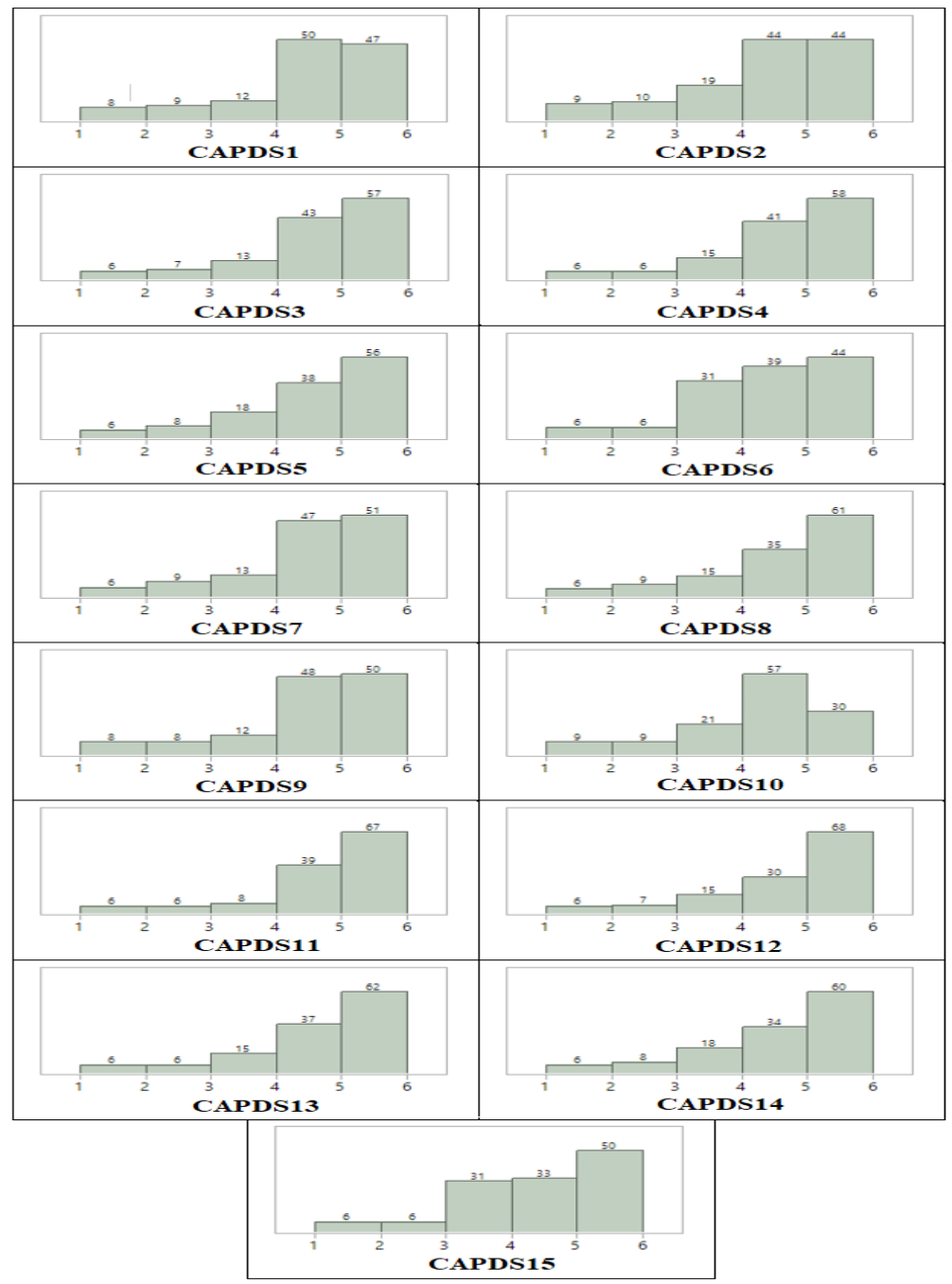

Source: Authors' research

Based on the table, and in accordance with the average rating of the analyzed claims, the order of significance of the asserted claims is as follows: CAPDS11 (4.2301587), CAPDS12 (4.1666667), CAPDS13 (4.1349206), CAPDS4 (4.1031746), CAPDS3 (4.0952381), CAPDS8 (4.0793651), CAPDS14 (4.0634921), CAPDS5 (4.031746), CAPDS7 (4.015873), CAPDS9 (3.984127), CAPDS1 (3.9444444), CAPDS15 (3.9126984), CAPDS6 (3.8650794), CAPDS2 (3.8253968), CAPDS10 (3.7142857). 


\section{3) Correlation and regression analysis}

The paper makes available a correlation and regression analysis related to the impact of the independent variable "Contact with customers" (hereinafter: CC) on the dependent variable "The competitiveness of the agricultural products distribution system" (hereinafter: CAPDS).

Table (Table 3.) provides descriptive statistics for the developed system model.

Table 3. Descriptive statistics for the variables of Customer Contact (CC) and the Competitiveness of the Agricultural Products Distribution System (CAPDS)

\begin{tabular}{|l|r|r|}
\hline & \multicolumn{1}{|c|}{ CC } & \multicolumn{1}{|c|}{ CAPDS } \\
\hline Mean & 3.962963 & 4.0111111 \\
\hline Std Dev & 1.1048155 & 1.0974799 \\
\hline Std Err Mean & 0.0984248 & 0.0977713 \\
\hline Upper 95\% Mean & 4.1577578 & 4.2046126 \\
\hline Lower 95\% Mean & 3.7681681 & 3.8176096 \\
\hline N & 126 & 126 \\
\hline
\end{tabular}

Source: Authors' research

Figure (Figure 4.) presents the Pearson correlation values for the independent variable Customer Contact (CC) and the dependent variable Competitiveness of the Agricultural Products Distribution System (CAPDS). The correlation coefficient between the mentioned variables (CC and CAPDS) is strong (0.9975).

Figure 4. Correlation coefficient for the CC and CAPDS variables

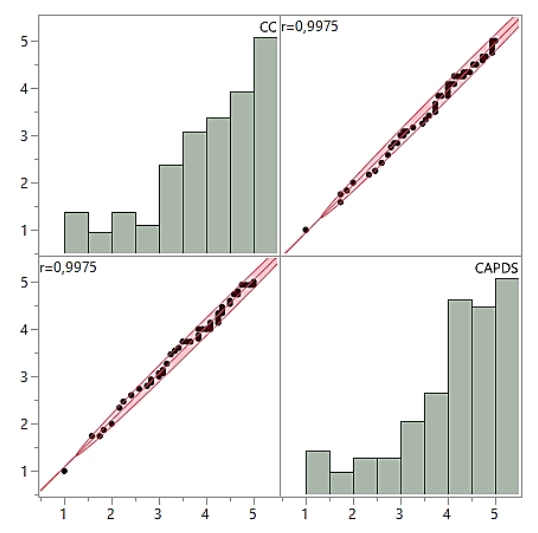

Source: Authors' research

A basic model evaluation was carried out in table (Table 4.). The coefficient of determination is 0.995079 , which means that with $99.50 \%$ of the variability of the dependent variable, CAPDS can be explained by the independent variable CC. 
Table 4. Model evaluation for the CC and CAPDS variables

\begin{tabular}{|l|r|}
\hline Rsquare & 0.995079 \\
\hline RSquare Adj & 0.99504 \\
\hline Root Mean Square Error & 0.077296 \\
\hline Mean of Response & 4.011111 \\
\hline Observations (or Sum Wgts) & 126 \\
\hline
\end{tabular}

Source: Authors' research

The statistical significance score is given in table (Table 5.) and it is $[\mathrm{F}(1.124)=$ $25075.35, \mathrm{p}<0.0001]$.

Table 5. ANOVA for the CC and CAPDS variables

\begin{tabular}{|l|r|r|r|r|}
\hline Source & \multicolumn{1}{|c|}{ DF } & \multicolumn{1}{c|}{ Sum of Squares } & Mean Square & \multicolumn{1}{c|}{ F Ratio } \\
\hline Model & 1 & 149.81692 & 149.817 & 25075.35 \\
\hline Error & 124 & 0.74086 & 0.005975 & Prob $>$ F \\
\hline C. Total & 125 & 150.55778 & & $<0.0001 *$ \\
\hline
\end{tabular}

Source: Authors' research

Table (Table 6.) determines the contribution of the independent variable $\mathrm{CC}$ to dependent variable CAPDS. On the basis of these data, the following hypothesis can be confirmed: "The level of customer contact influences the level of competitiveness of the agricultural products distribution system."

Table 6. Contribution coefficients for the CC and CAPDS variables

\begin{tabular}{|l|r|r|r|r|r|r|}
\hline Term & \multicolumn{1}{|c|}{ Estimate } & \multicolumn{1}{c|}{ Std Error } & \multicolumn{1}{c|}{$\mathrm{t}$ Ratio } & \multicolumn{1}{c|}{ Prob $>|\mathrm{t}|$} & \multicolumn{1}{c|}{ Std Beta } & \multicolumn{1}{c|}{ VIF } \\
\hline Intercept & 0.0841583 & 0.025737 & 3.27 & $0.0014 *$ & 0 & \\
\hline GH & 0.9909133 & 0.006258 & 158.35 & $<0.0001 *$ & 0.997537 & 1 \\
\hline
\end{tabular}

Source: Authors' research

Based on the data in the previous table, a regression equation can be formed, which reads as follows:

$y=0.0841583+0.99909133 \cdot x$

or

CAPDS $=0.0841583+0.99909133 \cdot C C$

Figure (Figure 5.) shows a diagram of the regression equation for the CC and CAPDS variables. 
Figure 5. Regression equation for CC and CAPDS variables

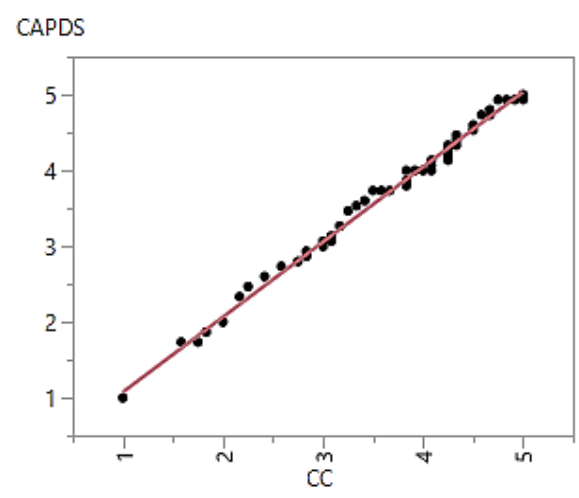

Source: Authors' research

\section{Conclusions}

The competitiveness of agricultural products is a complex phenomenon, though a phenomenon for which there is an attempt to find an explanation in as much detail as possible while clearly defining it. Accordingly, this paper highlights customer contact as part of the agricultural distribution channel and its impact on the competitiveness of agricultural holdings in Serbia.

The results of the empirical study show that all analyzed claims related to customer contact (CC) were rated with an average greater than 3.5, indicating that respondents agree with the claims made. In regards to the frequency of the responses, from 8 out of 12 statements $(2 / 3$, i.e. $66.67 \%)$, individually the most represented rating was 5 - completely agree (including one statement in which it shares the first place by the number of answers). The average highest rated claims (average $>4 ; 5$ claims, i.e. 41.67\%) were as follows: CC11 - Good customer relations are important for long-term planning for a distribution strategy, CC10 - Frequent buyers lead to profit increase, CC5 - Markets are important for meeting customer wants and needs, CC12 - Loyal customers significantly impact the planning of a distribution strategy, CC4 - Wholesale stores are increasingly important places to create customer contact.

The results of the empirical study also showed that all the analyzed claims regarding the competitiveness of the agricultural products distribution system (CAPDS) were evaluated with an average higher than 3.5 (minimum 3.7142857), which indicates that the respondents agree with the stated claims. When it comes to the response frequency of 13 out of 15 claims (86.67\%) individually, the most prevalent rating was 5 - completely agree (including one claim which shares the first place by the number of answers). The average best-rated claims (average $>4$; 5 claims, i.e. $41.67 \%$ ) were as follows: CAPDS11 - Familiarization of the farm with the way the market functions leads to a stronger competitive position, CAPDS12 - Introducing innovation 
in all elements of physical distribution leads to increasing the competitiveness of the agricultural products distribution system, CAPDS13 - A good distributor relationship affects competitiveness, CAPDS4 - Transportation management significantly affects the competitiveness of the agricultural products distribution system, CAPDS3 Warehouse modernization leads to an increased competitiveness of the agricultural products distribution system, CAPDS8 - The point of sale has an impact on increasing the competitiveness of the agricultural products distribution system, CAPDS14 - A good selection of distribution channels significantly increases the competitiveness of the agricultural products distribution system, CAPDS5 - Adequate commodity handling contributes to greater competitiveness of the agricultural products distribution system, and CAPDS7 - Inventory management affects the competitiveness of the agricultural products distribution system.

The correlation coefficient between the analyzed variables CC and CAPDS is strong (0.9975). Also, the coefficient of determination is 0.995079 , which means that with $99.50 \%$ of the variability of the dependent variable, CAPDS can be explained by the independent variable $\mathrm{CC}$. On the basis of all the above, it can be concluded that the object and purpose of the paper have been realized, and that the hypothesis of this paper "The level of customer contact influences the level of competitiveness of the agricultural products distribution system" has been proven, based on the conducted research and statistical calculations.

The contribution of this paper is reflected in the importance of increasing the competitiveness of the agricultural products distribution system, especially from the point of view of customer contact as part of the distribution channel of agricultural products in the territory of the Republic of Serbia (in which agriculture has a significant place in total economic activities). The research results also form the basis for further research in this field, both in the field of agriculture and in other fields of economy.

\section{Conflict of interests}

The authors declare no conflict of interest.

\section{References}

1. Aiginger, K., Bärenthaler-Sieber, S., Vogel, J. (2013). Competitiveness under New Perspectives, Work Package 301, MS46 «Research paper competitiveness under new perspectives», Working Paper no 44, October 2013, WWW forEurope, Retrived from https://www.oecd.org/eco/Competitiveness-under-New-Perspectives.pdf (13.12.2018, 13:33).

2. Anđelić, S., Garabinović, D., \& Šormaz, G. (2019). A REVIEW OF WINE AND WINE TOURISM PRESENCE IN THE SCIENTIFIC PAPERS IN JOURNALS IN THE FIELD OF TOURISM. Economics of Agriculture, 66(4), 1055-1090. doi: 10.5937/ekoPolj1904055A 
3. Aničić, D., Obradović, M., \& Vukotić, S. (2018). Impact of economic policy on the management of competitiveness of the agriculture sector in Serbia. Economics of Agriculture, 65(1), 187-200. doi:10.5937/ekoPolj1801187A

4. Becić, S., Stojanović, M., \& Nikolić, M. (2018). Role of marketing and social networks in improving business effectiveness. Ekonomika, 64(3), 77-88. doi:10.5937/ekonomika1803077B

5. Cambridge Dictionary, Retrieved from https://dictionary.cambridge.org/dictionary/ english/competitiveness $(13.12 .2018,13: 07)$.

6. Ćirić, M., Carić, M., \& Kuzman, B. (2018). Farmer innovativeness and its impact on Internet and social media adoption. Economics of Agriculture, 65(1), 243-256. doi: 10.5937/ekoPolj1801243C

7. Dimitrovski, D., Leković, M., \& Joukes, V. (2019). A bibliometric analysis of Crossref agritourism literature indexed in Web of Science. Hotel and Tourism Management, 7(2), 25-37. https://doi.org/10.5937/menhottur1902025D

8. Duvnjak, S. (2013). Directions for the development of activity of markets in Serbia. Business Association of Serbian Markets. [In Serbian: Duvnjak, S. (2013). Pravci razvoja pijačne delatnosti u Srbiji. Poslovno udruženje „Pijace Srbije“], Retrieved from http:/www.pups.rs/docs/pravci_razvoja pijacne delatnost.pdf $(28.06 .2019,15: 13)$.

9. Gajdić, D., Petljak, K., \& Mesić, Ž. (2018). An exploration of distribution channels: Challenges and opportunities for organic food producers in Croatia. Economics of Agriculture, 65(4), 1461-1482. doi: 10.5937/ekoPolj1804461G

10. Ilić, I. (2016). Analysis of consumption of organic products in Nišava district. Ekonomika. 62(2), 167-178. doi:10.5937/ekonomika1602167I

11. Kotler, P., Keller, K. L. (2006). Marketing management. Translated from the English twelfth edition of the book. DATA status, Belgrade. [In Serbian: Kotler, P., Keller, K. L. (2006). Marketing menadžment. Prevod sa engleskog jezika dvanaestog izdanja knjige. DATA status, Beograd].

12. Lamb, C. W., Hair, J. F., McDaniel, C. (2011). Marketing. South-Western Cengage Learning.

13. Lu, Y., Yang, Y., Lu, F., \& Sun, X. (2004). Study on Distribution Patterns of E-Business Based Agricultural Products Logistics. In The Fourth International Conference on Electronic Business (ICEB2004), Beijing, (pp. 169-174). Retrieved from https://pdfs.semanticscholar. org/75b7/3e4f3a6b04ba3925db9017c7cc72b4f47586.pdf $(20.05 .2019,09: 49)$.

14. SEEDEV (2017). Competitiveness of Serbian agriculture. SEEDEV. [In Serbian: SEEDEV (2017). Konkurentnost poljoprivrede Srbije. SEEDEV], Retrieved from https://www.seedev.org/publikacije/Konkurentnost poljoprivrede Srbije/ Konkurentnost_Srbije_Analiza.pdf (13.12.2018, 16:23).

15. Segetlija, Z. (2006). Distribution. Josip Juraj Strossmayer University, Faculty of Economics, Osijek. [In Croatian: Segetlija, Z. (2006). Distribucija. Sveučilište Josip Jurij Strossmayera, Ekonomski fakultet, Osijek]. 
16. Zakić, N., Bugarčić, M., \& Milovanović, M. (2017). Proclivity for open innovation in the case of agricultural and food companies in Serbia. International Review, (34), 64-71.

17. Zarić, V., Kovačević, D., Jovanović, V. (2016). Direct marketing of the Serbian agricultural products - drawbacks and opportunities. Ekonomske ideje i praksa, 21, 59-76. [In Serbian: Zarić, V., Kovačević, D., Jovanović, V. (2016). Direktni marketing poljoprivrednih proizvoda u Republici Srbiji - mogućnosti i ograničenja. Ekonomske ideje i praksa, 21, 59-76]. 